\title{
In vitro studies on peripheral blood leucocytes in rheumatoid arthritis
}

\author{
H. A. MÉnARd,* T. HAim, ANd A. P. PELTier \\ From Clinique Rhumatologique et Unité INSERM, Hôpital Lariboisière, Paris, France
}

Current concepts on the pathogenesis of rheumatoid arthritis (RA) centre on inflammation induced by immune complexes. These complexes consist mainly of IgG and IgG-rheumatoid factor present locally or sometimes systemically. This mechanism explains the superimposable deposition of immunoglobulins and complement in the synovial membrane and also many features of the rheumatoid synovial fluid: low complement levels, anticomplementary activity, and the presence in the leucocytes of immunoglobulins and complement. On the other hand, it does not readily explain the important mononuclear cell infiltration of the synovium. This infiltrate may mediate several reactions depending on its composition. Some of these cells are probably lymphocytes of the B variety (thymus-independent) that will eventually transform into secreting cells (plasma cells) contributing to the local production of antibody (Smiley, Sachs, and Ziff, 1968). These B-cells might have been attracted there by immune complexes via their membrane receptor for complement (Dukor, Bianco, and Nussenzweig, 1971). These cells could also be lymphocytes of the $T$ variety (thymus-dependent) participating in a delayed hypersensitivity reaction (Peltier, 1962). Since lymphocytic cells are presumably involved in the pathogenesis, we have chosen the circulating blood leucocytes as a model to approach the problem of cellular immune involvement in this disease.

In the present work the behaviour of peripheral blood leucocytes (PBL) of rheumatoid patients has been evaluated in terms ${ }^{3} \mathrm{H}$-thymidine uptake: spontaneous, induced by a nonspecific mitogen (phytohaemagglutinin (PHA)), and induced by immune-complexes made of human $O$ red blood cells coated with rabbit anti-human $O$ red blood cells.

The results obtained indicate an abnormal behaviour of RA-PBL cultivated alone or with PHA, but no influence of immune-complexes on ${ }^{3} \mathrm{H}$-thymidine uptake by these cells.

\section{Material and methods}

\section{LEUCOCYTES}

PBL were obtained from 25 subjects: fifteen patients with active seropositive RA, and ten control subjects (seven normal and three with inactive ankylosing spondylitis). 2 vol of heparinized (Calciparine Choay) venous blood were mixed with 1 vol of culture medium containing $3 \%$ gelatin. After gravity sedimentation at $37^{\circ} \mathrm{C}$ the leucocyterich supernatant plasma was removed and the cells centrifuged at 800 r.p.m. for 10 minutes at room temperature. After washing, the cells were adjusted at $2 \times 10^{6}$ mononuclear cells $/ \mathrm{ml}$ of culture medium.

\section{RED BLOOD CELLS}

Nonsensitized human $\mathrm{O}+$ red blood cells $(\mathrm{E})$ were washed in saline and resuspended in culture medium at concentrations ranging from 0.01 to $0.25 \%$. Sensitized red cells (EA) were prepared by mixing one vol of $1 \% \mathrm{E}$ and one vol of rabbit anti-O haemagglutinin (Institut Pasteur, Paris) diluted at $50 \%$ of its agglutinating titre. From these EA, suspensions ranging from 0.01 to $0.25 \%$ final concentration were prepared in culture medium.

\section{CULTURES}

All cultures were done in Eagle's medium supplemented with $30 \%$ calf serum and penicillin-streptomycin at a final concentration of $100 \mu \mathrm{g} / \mathrm{ml}$. Each Falcon plastic tube contained $0.5 \mathrm{ml}$ of reagent (PHA-M, Difco, E or EA suspensions, or culture medium alone), and $0.5 \mathrm{ml}$ of leucocyte suspension, i.e. $1 \times 10^{6}$ cells. Tubes were gazed with a mixture of $97 \% \mathrm{O}_{2}-3 \% \mathrm{CO}_{2}$ and tightly closed before incubation at $37^{\circ} \mathrm{C}$.

After 48 hours of culture, $0.1 \mathrm{ml}$ of a $1 / 100$ dilution of a stock solution of ${ }^{3} \mathrm{H}$-thymidine $\left({ }^{3} \mathrm{H}\right.$-Tdr) $1 \mathrm{mCi} / \mathrm{ml}$ (specific activity $1 \mathrm{Ci} / \mathrm{mmol} / \mathrm{l}$.) was added and cultures were terminated at 72 hours. The cell pellet was washed in saline, treated successively with $5 \%$ trichloroacetic acid, absolute methanol, and NCS solubilizer (Amersham-Searle). The final solution was mixed with $3 \mathrm{ml}$ of methanol and $14 \mathrm{ml}$ of a toluene-based scintillation fluid containing $100 \mathrm{mg}$ dimethyl-POPOP and $4 \mathrm{~g} \mathrm{PPO} / 1$. 10-minute counts were done using a Packard Scintillation counter and corrections were made for quenching. Results are expressed in 
counts per minute (cpm) per culture tube, and each value is the mean of triplicate culture.

\section{IMMUNE COMPLEX STIMULATION}

Each culture batch was made in two series. The first tube of each series contained $0.5 \mathrm{ml}$ of leucocyte suspension and served as the nonstimulated (spontaneous uptake) culture. In the other tubes, to $0.5 \mathrm{ml}$ of leucocyte suspension was added $0.5 \mathrm{ml}$ of $\mathrm{E}$ suspensions or $\mathrm{EA}$ suspensions at the following concentrations: $0.01,0.03,0.06,0.12$, and $0.25 \%$. The last tubes of each series served as positive controls and contained $0.5 \mathrm{ml}$ of leucocyte suspension and $0.5 \mathrm{ml}$ of a $1 / 32$ dilution of PHA-M stock-solution containing $1.5 \mathrm{mg}$ protein $/ \mathrm{ml}$.

\section{DATA PROCESSING}

Statistical evaluation of the data followed established principles for small series (Schwartz, 1969).

\section{Results}

SPONTANEOUS ${ }^{3} \mathrm{H}$-THYMIDINE UPTAKE

When PBL were cultured in the absence of mitogen, there was a spontaneous uptake of ${ }^{3} \mathrm{H}-\mathrm{Tdr}$ which was low in the control group $(300 \pm 121 \mathrm{cpm})(\mathrm{X} \pm \mathrm{SD})$ and higher in the RA group (765 $\pm 844 \mathrm{cpm})$ $(\mathrm{X} \pm \mathrm{SD})$. This difference is significant at the $\mathrm{P}<0.05$ level, though the dispersion of the values is greater in the RA group (Table I, Fig. 1).

Table I Spontaneous ${ }^{3} \mathrm{H}$-thymidine uptake in $\mathrm{RA}$ and control PBL cultures

\begin{tabular}{llll}
\hline & Control & & $R A$ \\
Sample & 10 & & 15 \\
Range (cpm) & $98-547$ & & $113-3278$ \\
Mean & 300 & 765 \\
SD & 121 & 844 \\
\hline
\end{tabular}

PHA-M INDUCED ${ }^{3} \mathrm{H}-\mathrm{Tdr}$ UPTAKE

Results are expressed as a PHA-stimulation index representing the ratio of optimally stimulated cultures with PHA to nonstimulated cultures (no PHA). The data are summarized in Table II and are shown in Fig. 2. This mean index is half the value in the RA group (12.24) of the control group (25.37). This difference may be not significant $(P>0.1)$ because of the great dispersion observed in both groups (Fig. 2). Nevertheless, eight RA patients had a very low index.

\section{RELATION BETWEEN SPONTANEOUS AND}

\section{PHA INDUCED ${ }^{3} \mathrm{H}-\mathrm{Td}$ r UPTAKE}

In all 25 cultures an inverse relation between the spontaneous uptake and the PHA stimulation index was observed (Fig. 3). The $\chi^{2}$ test $\left(\chi^{2}=5 \cdot 69\right)$ shows this relation to be significant $(0.02>\mathrm{P}>0.01)$. It is worth noting that all seven subjects with low index

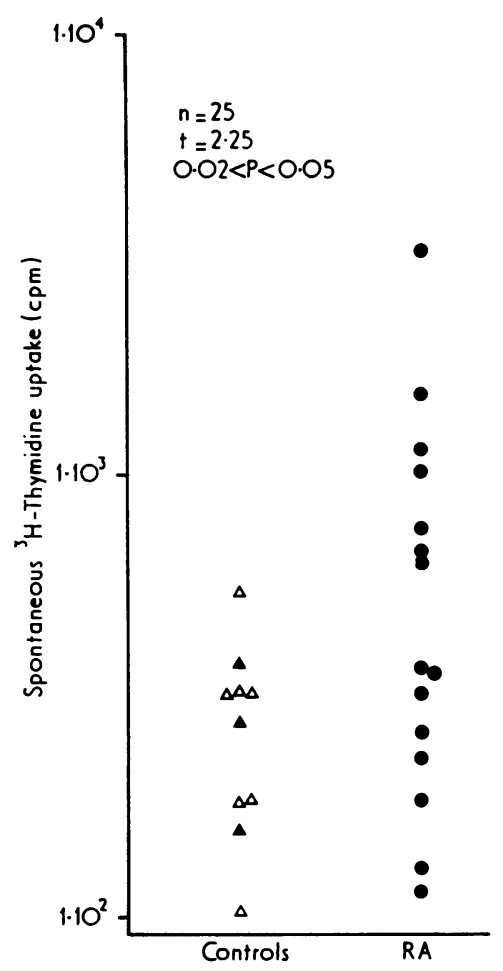

FIG. 1 Spontaneous ${ }^{3} H$-thymidine uptake in $R A$ and control PBL cultures. Symbols are the same in other figures. - $R A$ patients, $\Delta$ normal controls, $\Delta$ inactive ankylosing spondylitis

Table II PHA stimulation index in $R A$ and control $P B L$ cultures

\begin{tabular}{llll}
\hline & Control & $R A$ \\
\cline { 1 - 2 } $\begin{array}{ll}\text { Sample } \\
\text { Range }\end{array}$ & 10 & 15 \\
Mean & $\begin{array}{ll}1 \cdot 5-106 \\
25 \cdot 37\end{array}$ & $1-56 \cdot 5$ \\
\hline
\end{tabular}

(less than 3.5) and high spontaneous uptake (more than $650 \mathrm{cpm}$ ) are from the RA group.*

IMMUNE COMPLEX INDUCED ${ }^{3} \mathrm{H}-\mathrm{Td} \mathrm{r}$ UPTAKE Fig. 4 shows the results obtained by culturing rheumatoid PBL with increasing concentration of $E$ and EA. The curve for $E$ is flat, not significantly different from the spontaneous uptake, and shows the absence of nonspecific stimulation by erythrocyte. The curve for $\mathrm{EA}$ in this case is different from the $\mathrm{E}$ curve, mostly for the $0.01 \%$ and the $0.25 \%$ concentrations. For each concentration of cells a stimulation index can therefore be calculated (EAcpm/Ecpm) and plotted as shown on Fig. 5. In the statistical evaluation only the points giving the highest stimulation index for

* Since the completion of this work, another RA patient had a spontaneous uptake of $1,800 \mathrm{cpm}$ and a PHA index of 0.92 . 


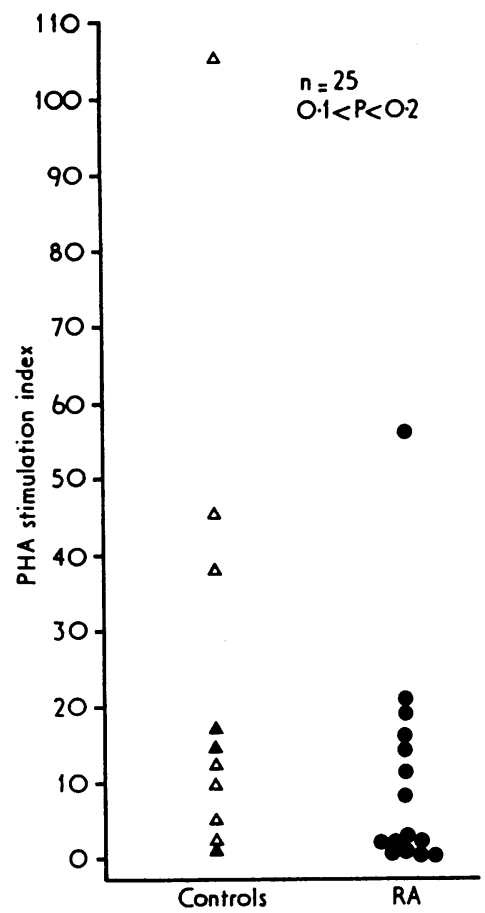

FIG. $2 P H A$ stimulation index in $R A$ and control $P B L$ cultures

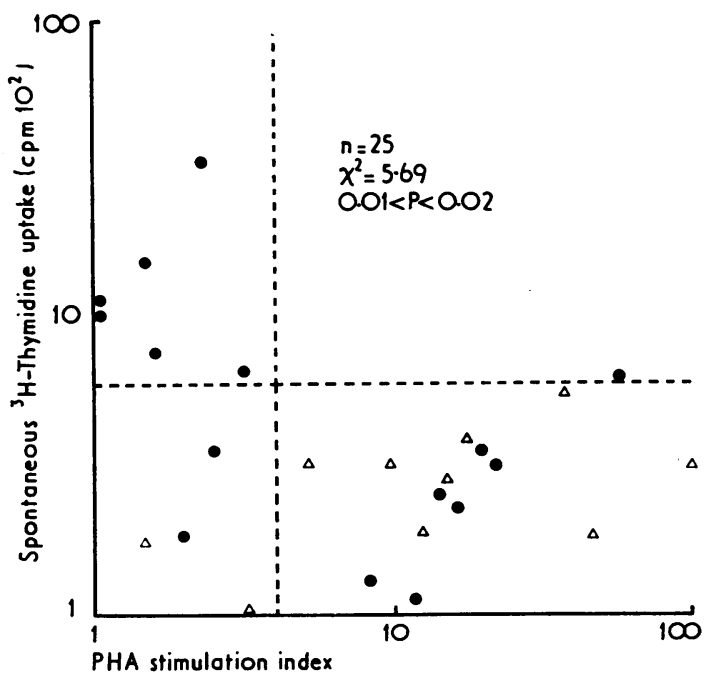

FIG. 3 Correlation between spontaneous and PHA induced uptake of ${ }^{3} \mathrm{H}$-thymidine in $R A$ and control $P B L$ cultures

each set of culture were retained. The data for the 25 cultures are shown in Table III and Fig. 6. The mean uptake for EA is higher in the RA group. Similarly the index is greater than in controls (2.04 v. 1.48). This is not statistically significant, probably because

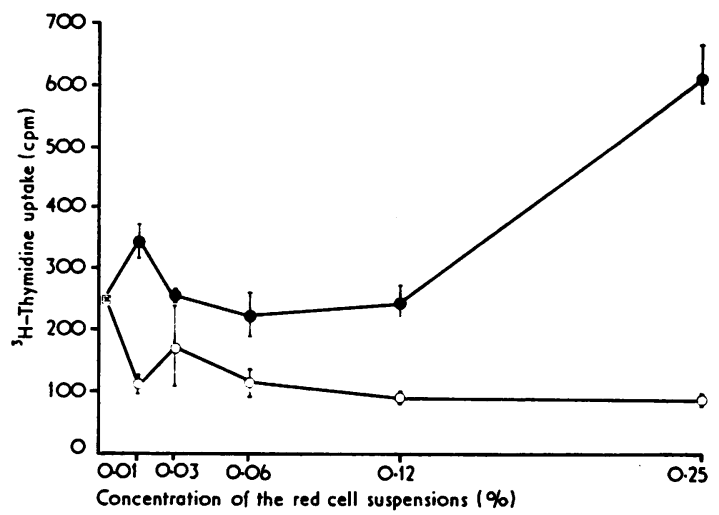

FIG. 4 Dose-response curve of ${ }^{3} \mathrm{H}$-thymidine uptake in rheumatoid PBL cultures induced by $E \bigcirc$ and EA $\bullet$ cultures

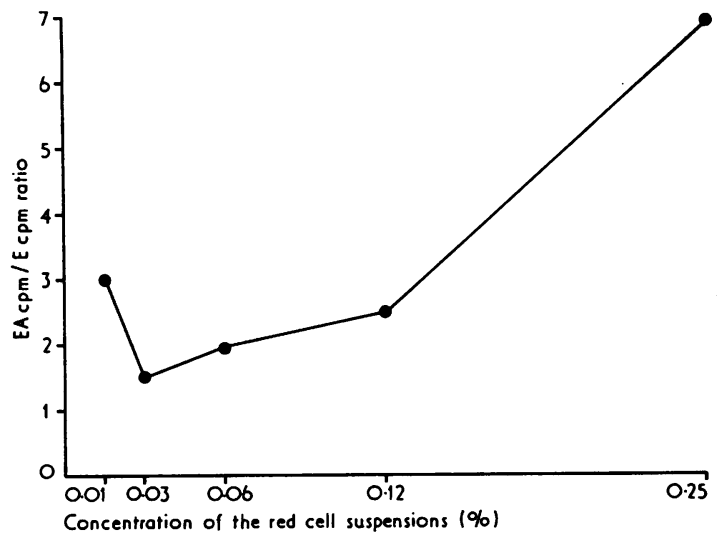

FIG. 5 Dose-response curve of immune complexes stimulation index (EAcpm/Ecpm) in rheumatoid PBL cultures

Table III Immune complex stimulation in $R A$ and control PBL cultures

\begin{tabular}{|c|c|c|}
\hline & Control & $R A$ \\
\hline $\begin{array}{l}\text { Sample } \\
\text { Spontaneous } \\
\text { uptake (cpm) }\end{array}$ & $\begin{array}{l}10 \\
300(98-547)\end{array}$ & $\begin{array}{l}15 \\
765(113-3278)\end{array}$ \\
\hline $\begin{array}{l}\text { EA induced } \\
\text { uptake (cpm) }\end{array}$ & $340(185-507)$ & $1094(286-3850)$ \\
\hline $\begin{array}{l}E \text { induced } \\
\text { uptake (cpm) }\end{array}$ & $239(104-484)$ & 732 (89-2653) \\
\hline $\mathrm{EA} \mathrm{cpm} / \mathrm{E} \mathrm{cpm}$ & $1.48(1.04-2.57)$ & $2.04(1.05-6.74)$ \\
\hline
\end{tabular}

of irregular distribution and great dispersion. Only three out of ten RA patients have an index higher than controls.

\section{Discussion}

The results described in the first part of this work suggest a peculiar behaviour of rheumatoid PBL: 


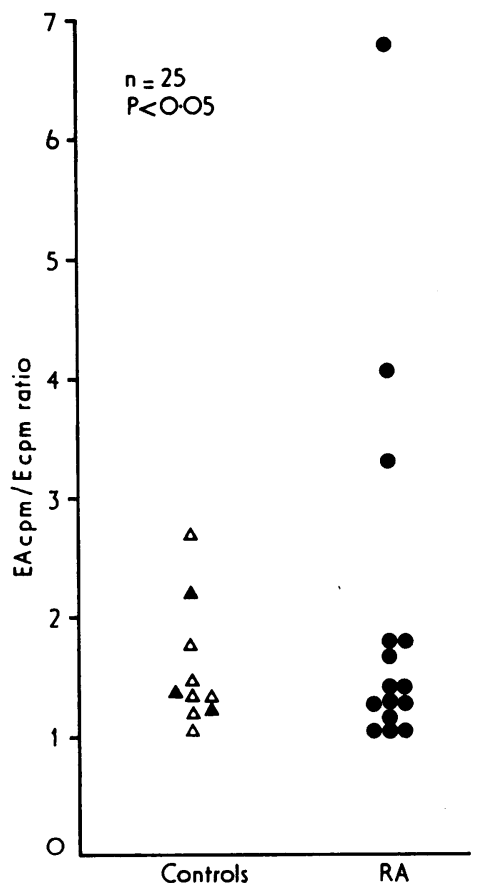

FIG. 6 Immune complex stimulation index in $R A$ and control PBL cultures

when cultured without stimulation they incorporate significantly more ${ }^{3} \mathrm{H}-\mathrm{Tdr}$ than controls. On the other hand, when cultured with PHA they tend to incorporate less. There is a significant inverse relation between spontaneous uptake and PHA-induced uptake. The interpretation of these data is made difficult by the uncertainty as to the identity of the incorporating cells. Because no further morphological or functional (e.g. phagocytosis) studies were made, we can only speculate upon the cellular nature of the phenomenon.

The first possibility is that the spontaneously incorporating cells are monocytes of bone marrow origin. These would be macrophage precursors prematurely liberated from the marrow in the context of an inflammatory event. Horwitz and co-workers studied spontaneous uptake of PBL in inflammatory diseases: systemic lupus erythematosus, adult and juvenile RA, and infectious diseases (Horwitz, Stastny, and Ziff, 1970). During the first 5 hours of culture the radioactive cells were nonphagocytic mononuclear cells which eventually acquired phagocytic capacity (Horwitz and Steagall, 1972). Some of these cells clearly looked like macrophages, while others were analogous to stress lymphocytes (Frank and Dougherty, 1953), atypical lymphocytes (Wood and Frenkel, 1967), or to antigen-stimulated recirculating small lymphocytes (Everett, Caffrey, and Rieke, 1964). The important difference with the present work is that in Horwitz's experiment the cells were in contact with ${ }^{3} \mathrm{H}$-Tdr from 0 to 5 hours, while in this study the uptake was measured from 48 to 72 hours. Since the maturation time of macrophage precursors is 24 to 48 hours, it is probable that the 48-hour macrophages are not incorporating ${ }^{3} \mathrm{H}-\mathrm{Tdr}$ any more and are thus not involved in our observations.

The second possibility is that the spontaneous uptake is due to lymphocytic activity. This spontaneous incorporation could be due to stimulation by antigen(s) contained in the added calf serum, or else it could be an in vitro carry-over of an activation in vivo. This last situation would be comparable to the high spontaneous uptake in lymph node and spleen cells of immunized animals (Loewi, Temple, and Vischer, 1968; Martin-Taieb, Peltier, Mondet-Leroy, and Kourilsky, 1970). Further evaluation by morphological and functional criteria will be needed to identify the cell type responsible for these observations in rheumatoid PBL.

The nature of the responding cell in PHA-induced blastogenesis has been investigated and the consensus is that a thymic-derived lymphocyte (T-cell) is involved. The low PHA response in rheumatoid PBL reported by Leventhal, Waldorf, and Talal (1967) is not readily explained. There might be a low circulating T-cell count; Williams, DeBoard, Mellbye, Messner, and Lindström (1973), in a recent work, have found a great variation (14-98\%) of the per cent. $T$ lymphocyte in rheumatoid PBL. This group has also noted that there was a tendency to low percentages in more severe forms of the disease. It will be interesting to look at the clinical make-up of our low PHA responder group. Secondly, there could also be a relative $\mathrm{T}$-cell inefficiency as detected in the blas transformation test, if these cells were already committed and engaged in vivo in an immune response. This would explain the inverse relationship between spontaneous uptake and PHA response.

In the latter part of this work, the PBL response in vitro to immune complexes was studied. As the complexes were made of rabbit antibody and human red cell, the test system was in fact the cellular counterpart of the serological reaction for rheumatoid factor (Eyquem's modification of the WaalerRose test (Eyquem and Podliachouk, 1959). The data show that even if the ${ }^{3} \mathrm{H}-\mathrm{Tdr}$ uptake was higher in the RA group when cultures contained EA, it never reached a level of significance and presumably only reflects nonspecific reactivity as already mentioned. In fact, the response to EA parallels the spontaneous uptake (Table III). Taken as a whole, these data do not show a blastic effect of immunologically altered $\gamma$-globulins on rheumatoid PBL. These findings of a lack of cellular reactivity to altered $\gamma$-globulins are similar to those of other workers using different systems in vitro (Runge and Mills, 1958; Kačaki, Bullock, and Vaughan, 1969). They are also compatible with our own 'in vivo' studies, where it was shown 
that skin testing rheumatoid patients with altered $\gamma$-globulins did not result in any local delayed reaction (Peltier, Lermusiaux, Kuntz, and Ryckewaert, 1973), On the other hand, using the migration inhibition factor test on rheumatoid PBL with IgG as the antigen, several groups have found reactivity (Fröland and Gaarder, 1971; Serre, Simon, Mandin, Sany, and Clot, 1972; Eibl, 1972). At the present time it is not possible to reconcile these findings, and further work is needed.

\section{Summary}

Blastic transformation as measured by tritiated thymidine uptake was studied in peripheral blood leuco- cyte cultures of seropositive rheumatoid arthritic patients and in cultures of controls. Spontaneous uptake tended to be higher in the RA group and there was a significant inverse relation between this value and the one obtained after PHA stimulation. A third of RA patients did not respond to PHA. Lastly, stimulation by immune complexes (rabbit antihuman red cells, human red cells) was absent in both groups. It is suggested that the high spontaneous uptake seen in the RA group may be an in vitro carryover of events in vivo. As far as blastic transformation is concerned, this work does not support cellular reactivity against immunologically altered rabbit $\gamma$-globulins as a regular phenomenon in rheumatoid arthritis.

\section{References}

Dukor, P., Bianco, C., ANd Nussenzweig, V. (1971) Europ. J. Immunol., 1, 491 (Bone marrow origin of the complement receptor lymphocytes)

EiBL, M. (1972) Z. Immun.-Forsch., 144, 103 (Demonstration of cellular immunity towards homologous and aggregated autologous as well as towards complex-bound IgG in primary chronic polyarthritis)

EVerett, N. B., Caffrey, R. W., AND Rieke, W. O. (1964) Radiat. Res., 21, 383 (Radioautographic studies of the effect of irradiation on the long-lived lymphocyte of the rat)

Eyquem, A., AND Podliachouk, L. (1959) In 'Diagnostic Biologique des Rhumatismes Inflammatoires Chroniques', p. 123. Edition de la Tourelle, Paris

Frank, F. A., AND Dougherty, T. F. (1953) J. Lab. clin. Med., 42, 538 (The assessment of stress in human subjects by means of quantitative and qualitative changes of blood lymphocytes)

Fröland, S. S., AND GAARDER, P. I. (1971) Lancet, 1, 1071 (Leucocyte-migration inhibition induced by IgG in rheumatoid arthritis)

Horwitz, D. A., Stastny, P., AND Ziff, M. (1970) J. Lab. clin. Med., 76, 391 (Circulating DNA-synthesizing mononuclear leucocytes)

- ANd Steagall, R. V., JR. (1972) J. clin. Invest., 51, 760 (The development of macrophages from large mononuclear cells in the blood of patients with inflammatory disease)

KaČAKI, J. N., Bullock, W. E., AND VAUGHAN, J. H. (1969) Lancet, 1, 1289 (Failure of lymphocyte transformation in response to gamma-globulins in rheumatoid arthritis)

LeVenthal, B. G., Waldorf, D. S., AND TALAL, N. (1967) J. clin. Invest., 46, 1338 (Impaired lymphocyte transformation and delayed hypersensitivity in Sjögren's syndrome)

Loewi, G., Temple, A., AND Vischer, T. L. (1968) Immunology, 14, 257 (The immunological significance in the guinea-pig of in vitro transformation of lymph node, spleen and peripheral blood lymphocytes)

Martin-Taieb, C., Peltier, A., Mondet-Leroy, C., AND Kourilsky, R. (1970) Ann. Inst. Pasteur, 119, 572 (Action de l'extrait thyroïdien homologue sur les cellules ganglionnaires de cobaye en culture au cours et en dehors de la thryoïdite auto-allergique expérimentale)

Peltier, A. (1962) Rev. franç. Etud. clin. biol., 7, 770 (Rôle possible de l'hypersensibilité retardée dans la polyarthrite rhumatoïde)

-, LermusiauX, J. L., Kuntz, D., AND RyCKewaert, A. (1973) Rev. Rhum., 40, 497 (Recherches sur la réactivité cutanée à des préparations d'immunoglobulines $\mathbf{G}$ (IgG) isologues et autologues au cours de la polyarthrite rhumatoïde)

RuNGE, L. A., AND MilLs, J. A. (1958) Arthr. and Rheum., 1, 142 (In vitro and in vivo response to autologous IgG in patients with rheumatoid arthritis).

Schwartz, D. (1969) In 'Méthodes Statistiques à l'usage des Médecins et des Biologistes', 3rd ed., p. 82. Flammarion, Paris

Serre, H., Simon, L., Mandin, J., Sany, J., and Clot, J. (1972) Sem. Hôp. Paris, 48, 323 (Perturbations immunologiques au cours de la polyarthrite chronique rhumatismale)

Smiley, J. D., SACHS, C., AND ZIFF, M. (1968) J. clin. Invest., 47, 624 (In vitro synthesis of immunoglobulin by rheumatoid synovial membrane)

Williams, R. C., DeBoard, J. R., Mellbye, O. J., Messner, R. P., and Lindström, F. D. (1973) Ibid. 52, 283 (Studies of T- and B-lymphocytes in patients with connective tissue diseases)

Wood, T. A., AND Frenkel, E. P. (1967) Amer. J. Med., 42, 923 (The atypical lymphocytes) 